\title{
VALIDATION OF LEARNING THEORIES IN THEIR RELATIONSHIP WITH INFORMATION AND COMMUNICATIONS TECHNOLOGY
}

\author{
Dr. Jose CAPACHO \\ Systems and Computer Science Engineering Department \\ Universidad del Norte \\ Barranquilla, Colombia
}

\section{ABSTRACT}

The paper presents the conceptual basis of the theories: Behaviorism, Gestalt, Cognitive Psychology, and the Historic-Cultural Psychology. The essential categories of these theories were validated in a population of 2704 courses at the Massachusetts Institute of Technology, MIT (USA). The research seeks the relationship of theories with course design and student learning process supported by ICTs. The results for a sample of 629 open courseware analyzed gives the conclusion that the concepts of the theory of Piaget are the most influential in the process of eLearing of students in a $49.92 \%$.

Keywords: Behaviorism, Gestalt, Cognitive Psychology, Historic-Cultural Psychology, elearning, ICT.

\section{INTRODUCTION}

The student's learning in virtual spaces depends on the pedagogical approaches that are used in the design and operation of the course supported by ICTs. In eLearning two disciplines are integrated that are the Education and the Science of the Computing. Education provides pedagogy and virtual didactics while computing provides the platform for tele-training. In the process of training with ICTs it is not easy to identify the fulfillment of the pedagogical approach in the teaching-learning process of the student within the platform. The need for the paper is justified because it is necessary to guarantee the coherence between the pedagogical approach of the virtual course and the actions of the elearning process.

Then, based on the above, the paper develops: The formal foundations of pedagogical approaches: Behaviorism, Gestalt, Cognitive Psychology, and the Historic-Cultural Psychology and their state of the art. The selection of a set of virtual courses. Selected courses are MITOPENCOURSEWARE in the Massachusetts Institute of Technology - MIT. The evaluation of the courses in relation to the fulfillment of the pedagogical approaches used. The validation of the fulfillment of the pedagogical approaches in the virtual courses. The conclusion of the pedagogical approach most used in the virtual teaching-learning process of the selected university (MIT, USA).

The most used pedagogical approach defines the type of university within the categories of knowledge to learn, to develop, and to investigate. This implies if the tendency of the university in the process of elearning of the students tends toward teaching or research. 


\section{THEORETICAL FOUNDATIONS}

\section{Behaviorism Theory and Its Relation to ICTs}

Behaviorism in its relationship with ICT has been studied by: i) Psychological approaches which see it as learning scenarios supported by worksheets and exercises that serve to learn (Gebremeskel, Kebede, \& Chai, 2016) ii) For educators teaching strategy where applying game theory emphasizes measures to stimulate response (Paraskeva, Mysirlaki, \& Papagianni, 2010). iii) Education, considering the level of tools that define eLearning as a mixture of several educational trends of which is behaviorism (Evgeniou \& Loizou, 2012), or by analyzing ICT with a focus ranging from objectivism related the computer instruction to social constructivism (Nawaz \& Kundi, 2010). iv) Joint Disciplines psychologistseducators interested in analyzing the role of ICTs in relation to Behaviorism (Gebremeskel et al., 2016). v) For methodological analysts to discuss pedagogical models in eLearning and differentiating factors (Gonzalez Guerrero \& Ojeda, 2013). vi) Technical analysts in order to relate the levels of behaviorism teaching eLearning (Hussain, 2012). vii) Evaluators learning in order to analyze the implications of the use of behaviorism in eLearning (Alzaghoul, 2012). ix) Designers to build materials with a focus on instructional design (Yildirim, 2017) . Then, assessing research contributions in the aforementioned authors, given the multiple approaches and disciplines, it is not possible to identify an integrated theory of Behaviorism relationship with ICTs; therefore, this paper will present from the bottom of behaviorism in its integrated relationship with education technologies for virtual training processes supported by ICT psychological approach.

Behavioral theories or associationists have in Pavlov and Skinner its main representatives in the theories of classical and instrumental Behaviorism respectively. The conception of education becomes a technology represented by a sequence of mechanical actions consist stimulus - reply - reinforcements (Farhan, Aslam, Jabbar, Khalid, \& Kim, 2017), aimed at achieving the Behaviorism of the subject's behavior. Conception based on the following principle "Man is the product of the reinforcing environmental contingencies" (Perez, A., 1995, p. 37).

The process of classical Behaviorism of Ivan Pavlov

first it consists in the presentation of an unconditioned stimulus (US) inducing an unconditioned response (RI) ... present the neutral stimulus shortly before submitting the US. Pavlov used to use a metronome (...). The metronome had become a conditioned stimulus (CS) which caused a similar orgininal RI conditioned response. (Schunk, D., 1997, p. 35).

To B. F. Skinner Behaviorism it is achieved not only through the response, but because of environmental reinforcement; in this regard, "The reinforcing Behaviorism that interests Skinner is the presentation of the unconditioned stimulus, not the answer that occurs to him" (Hilgard, E and Bower, G., 1973, p.130); therefore student learning is achieved through the stimulus (S) -answer (A)-reinforcement ( $R$ ) sequence.

The relationship of Behaviorism to ICTs is supported by the interaction of the subject and external environment; applied to education it implies the subject from whom the virtual space is waiting for a response (reply) is stimulated by the component systems of the areas of information and communication based on the pedagogical and teaching approach used in the vrtual environment. The reinforcement received by the subject's behavior is derived from the external world stimuli captured. In this sense, the subject to interact with the virtual training environment receives stimuli (S) contained in the learning space; stimuli are represented by all components of the virtual space. Of course, web pages, learning objects, dynamic images, micro worlds are educational stimuli received by the trainee, on which the subject must answer (A), and for which, depending on the response, receives a reinforcement (R) (Klašnja-Milićević, Vesin, Ivanović, Budimac, \& Jain, 2017). 
Depending on the above analysis, there is a direct relationship between Behavioral Theory and ICT applied to training processes in virtual spaces; and several applications of Behaviorism in the classroom involve the use of technological tools such as programmed instruction. Computer programmed instruction

Trains students to work individually as he will demand an active participation in the learning process. Since technology has come to integrate the teaching-learning process, computer-assisted instruction has emerged as an application of Behaviorism. (Lawrence, T., 2005, p.28).

Based on the above, elaborations such as reinforcement's programs, teaching machines and programmed instruction present in the stimulus-response theories, have their parallel counterparts in virtual learning environments with ICT; that is, the virtual environment itself is a machine made in software that teaches the subject and whose functionality is expected that students learn. The reinforcement program has its equivalent in virtual environments with the presence of virtual activities containing drill and practice processes that constitute additional stimuli or reinforcements when the student has not reached learning achievements (Chung \& Wu, 2017).

Gestalt Theory and Its Relation to Learning in Virtual Spaces Supported by ICTs

The state of the art of Gestalt theory in its relation to ICT is very scarce in its content in English, and is presented below. School Gestalt regarding virtual education emphasizes the fact that students must know and understand fully the learning environment $(\mathrm{Hu}, \mathrm{Wu}, \&$ Shieh, 2016), which involves visualizing the virtual space in its organizational structure. This structure allows indivuales experiences and collaborative learning, understanding the display space as a possibility student to find patterns and make sense of a set of information of virtual space (Anaya, Luque, \& Peinado, 2016). Which it is an holistic sense as a whole (Burden, Aubusson, Brindley, \& Schuck, 2016). Therefore understand the virtual space as an organized structure, which contains information to learn is the synthesis of the theory mentioned in relation to ICTs.

Based on the above, it should be noted that not only is a difficulty the lack of research articles that address the Teory of Gestalt processes virtual training but the little information there does not treat postultados's Gestalt in its relationship with eLearning training processes. Therefore this research tries to find the relationship between Gestalt theory and ICTs.

Gestalt is a current interpretation of learning which opposes the mechanical orientation of behaviorism and whose most important representatives are Wertheimer, Koffka and Lewin and others. One of the most important contributions of Gestalt Theory in relation to learning is the copy of the laws of the organization, specific to the field of perception, applicable to learning, which is confirmed by the following fact:

The starting point for the treatment of Koffka learning is the assumption that the laws of the organization's own perception, are equally applicable to learning. (Hilgard, E. Bower, G., 1973, p. 262).

The discovery of the concepts of the student in the teaching activities of the virtual learning space permits his/her learning; therefore, the success of student learning is secured to the perception of virtual space, and consequently ensures the perception in the virtual space with a well-designed interface that will show the student's organization, background, shape, concepts, images, links, learning objects and graphic design in general. Then the Gestalt Theory views the conduct as an organized whole (Perez, A., 1995, p. 41). The organizing principle is crucial to maintaining the stability of the system and according to its stable state to perform their pre-set functions; of course, the system of human behavior, applying the principle of organic nature, should be considered fully. 
A platform supported by ICT, in order to comply with e-learning processes, is a system with hardware, software, comware (communications) to which must be added the -orgware(human talent) or organization whole system of virtual training. The interaction subjectvirtual space encompasses a interaction teacher-virtual space- student, which does not imply presencialidad. Behavioral behavior of student and teacher, considered as wholes organized as a whole but different, are integrated into the virtual space to meet a bidirectional transfer behavior between who teaches and who learns using the virtual environment, thus generating a system organized whose operation can not be split.

According to Gestalt Theory, the whole, interpreted as "the phenomena of learning and behavior, it is more than the sum linear juxtaposition of its parts." (Perez, A., 1995, p. 41). The synergy generated by the system, in this case, "the educational system of the virtual classroom and information and communication system" when the student learns in the virtual environment, it is more than the sum of its parts.

It is of utmost importance the definition of field of Gestalt theory understood as:

(...) The total psychological world in which the person operates at a given time. It is this set of interacting forces around the individual responsible for the learning process. They consider learning as a process of donating sense of meaning, to situations in which the individual is located. (Perez, A., 1995, p. 41).

The concept of field applied to formation processes in virtual spaces, allows the interrelation between cognitive field of the person with the field of virtual space; cognitive field that is necessarily influenced by the virtual space and whose interaction the student learns to virtual level. Field theory contains a didactic wealth such that the holistic and systemic interpretation of behavior allows the explanation of more complex learning as interpreted by the Gestalt. Then the conceptual teaching, such as problem solving, support more complex learning; (Slavík, Janík, \& Najvar, 2017). This, reaffirmed by the fact that:

An important educational application of Gestalt Theory is in the area of productive thinking (problem solving). (Duncker, 1945; Luchins, 1942; Wertheimer, 1945 cited by Schunk, D., 1997, p. 57).

So in a global sense (holistic), spaces of virtual training through the stated educational, allow the development of higher learning in the subject. Gestalt Theory attaches fundamental importance to the meaning; because it is precisely the meaning which allows conceptual change the subject from an initial to a final state of learning status; meaning they can only be achieved if the subject has an intrinsic motivation for what he wants to learn. In this sense, motivation according to Gestalt allows for creativity of the subject (Angelis, 2017). When student motivation through the virtual space is increased, expanding learning processes that allow student creativity are generated; nobody is interested in learning what you do not like; but, you learn more than required, when the taste for learning is accompanied by this intrinsic motivation in the subject and, consequently, in the community of the virtual classroom.

The above analysis leads to the conclusion that the essential categories related to conduct in the framework of Gestalt Theory, such as organized whole, synergy, holistic and systemic and motivation, they are also present in learning with ICT (E. A. Railean, 2017). Learning that involves the transformation in understanding the subject in relation to knowledge of the virtual class and is what constitutes the new mark in the learning process, expressed the distinction between process and footprint Koffka follows "The process is continues due to this stimulation; footprint is the result of previous processes " (Hilgard, E and Bower, G., 1973, p 268.); therefore, the process is effective only if it forms traces of student learning; otherwise, the teaching-learning process becomes a continuous cycle of stimulation, but without any results to the cognitive structure of the subject. 
Cognitive Psychology and Its Relationship with ICTs

Cognitive Psychology in their relationship with ICTs has been studied by: i) Affective developer eLearning applications (Thompson \& McGill, 2013). ii) Digital game developers to control processes supported by instruction (Tettegah, McCreery, \& Blumberg, 2015) technology. iii) Persons interested on an analysis of cognitive styles in virtual training (Jovanovic, Vukicevic, Milovanovic, \& Minovic, 2012) groups. iv) Developers adaptive learning systems considering congitivos and learning styles (Yang, Hwang, \& Yang, 2013). v) Developers of eLearning systems used to solve problems (QUTECHATE, Almarabeh, \& Alfayez, 2014). vi) Developers of educational environments interfaces in problem-based learning (PBL Problem-based learning) (Chua, Liu, \& Tan, 2015). vii) Neurophysiologists to study brain activity in sets supported by virtual environments (Ninaus et al., 2014). viii) Virtual Teachers interested in analyzing the impact of cognitive skills in learning with ICT (Sethy, 2012). ix) Evaluators online learning in relation to consider nuclear concepts (target) of Piaget's theory (Lopez, Morales, Hedlefs, \& Gonzalez, 2014). x) EDT's users (Educational Data Mining) in order to analyze the cognitive models that map the competencies required by students in solving a problem with student logs (Romero \& Ventura, 2013).

Given research in the area of Cognitive Psychology their relationship with ICTs, it is noted the multiple approaches and in turn the multiple disciplines that treat the above relationship; however, it is not clear in the documentary bases for use in investigations of the relationship mention, the study of the essential tenets of Piaget's theory in relation to ICT; which are presented below in order to analyze the direct relationship Cognitive Theory processes with training in virtual spaces supported by ICT.

The relation of Cognitive Psychology ICT will be developed from the perspective of the relationship between the means of virtually -the learning environment- the knower, in the learning process. The analysis of the aforementioned relationship cannot be performed without identifying the general conception of intellectual functioning virtual apprentice. John H. Flavell, regarding the functioning of intelligence, says that Piaget

He tried to reveal the basic and irreducible properties of cognitive adaptation that applies to all levels of development. These fundamental properties unchanged and will be in the functional aspects of intelligence, not structural; the functional characteristics form the core intellectual, with the words of Piaget, the intellectus ipse- makes possible the emergence of cognitive from the interrelationships of the organism and the environment structures. (Piaget (1952c, p.2), cited by Flavell, J., 1998, p. 61).

Then, starting from the fact that cognitive adaptation applies to all levels of development, it is necessary to identify the functional invariant properties of intelligence, because they are such features which allow adaptation between the knower and the virtual environment within an organizational framework, enable students to learn through virtual learning space. The functional invariants defining characteristics become intellectual functioning and essence are

(...) The organization, and adaptation, the second is subdivided into two interrelated components assimilation and accommodation. These invariants provide the critical link between biology and intelligence (...). (Flavell, J., 1998, p. 64).

Biologically adaptation is the process through which a living being changes its anatomic structures as a result of its interaction with the environment in which it develops; the adaptation of the organism to the environment 


\section{(...) Has the effect of modifying the first so that further enhances the rear are favorable to the preservation of the body exchanges. (Flavell, J. (1998, p. 64)).}

In this sense the initial cognitive structures (initial learning or less complex) operative in the life of the subject field that interacts with the virtual training space in biological domains of audio, vision, touch and smell, are transformed into new cognitive structures, giving as a result the construction of new learning more complex (final apprenticeship or after the subject has interacted with the virtual space).

Now, the interrelated components that support adaptation are assimilation and accommodation; understood as:

\section{(...) Assimilation integration process ... of objects or new knowledge to old structures (...) and accommodation, reformulation and development of new structures as a result of the previous addition. (Perez, A., 1995, p. 43).}

Then, functional adaptation and intellectual invariant subject based on assimilation allows knowing subject interact with the object knowledge of the virtual environment, thereby restructuring the initial knowledge of the subject as a result of the influence of the virtual space is generated (Kläre, 2017); which reaffirms the views expressed by Piaget who argues that assimilation is "the process of molding a fact of reality to the pattern of the developing structure of the subject" (Flavell, J., 1998, p. 68). For its part, the accommodation allows progress in learning the subject to enable new knowledge structures as a result of the incorporation generated in the initial structures of the subject, the conceptual features present in the object of knowledge contained in space for virtual training; which is confirmed by the fact that "the essence of accommodation is precisely this process of adapting to the varied demands or requirements that the world of objects imposes on the subject" (Flavell, J., 1998, p. 64).

Initial knowledge structures condition the learning of the subject according to Piaget; that is, the more elaborate instruments are managed by the subject knowledge better the intellectual operations of the individual. A virtual space creates opportunities to assess and evaluate the initial structures of knowledge of the student and maintain a permanent monitoring of student learning states change depending on both the instruments of knowledge and operations of his intellect, to interact with information present in the virtual space; learning states representing the change of cognitive structures subject (Winterhalder, 2017).

The adaptation of the subject, as -External internal cognitive relationship (subject) (virtual environment) depends on the concepts of assimilation and accommodation. The adaptation of the subject in a virtual space is understood in two ways. First, the subject is suited to the medium, or equivalently, if the cognitive structures of the subject is not suited to the dynamics of computer processes and communication of current and future world, their cognitive structures remain static and will not be competitive for informational and global society subject. Second, the virtual space is adaptive to the subject (adaptive hypermedia); ie it can be adaptive to the object in the virtual space to the subject, it favors both assimilation and accommodation of the information in the structures of existing knowledge in the learner (E. Railean, 2017).

Then intellectual adaptation is an act of intelligence in which the functional invariants, assimilation and accommodation, reach a steady state condition, or equivalently, are in a kind of balance; balance not being complete, it is possible only if the subject achieves an intellectual organization conceived as a whole; point at which the outline of the subject as a whole has internalized this conceptual scheme in virtual learning space; technological schemes whose architectural designs correspond to "linear, reticular, hierarchical, network 
or hybrid" design structures (Pressman, R., 2002, pp. 527-530), in which the teachings of the virtual space are contained as totalities .

In short, the two basic functional invariants of intellectual functioning of the subject are the organization and adaptation. The assimilation and accommodation are the basis of adaptation. The constant operation of aforementioned allow the formation of units of knowledge called schemes, whose development in time are knowledge systems and biological-intellectual subject development allow the passage of the subject of a concrete thinking to formal thought, provided when the student has motivationn to interatuar with virtual space.

Motivation is the seed of cognition, as an engine of cognition motivation (Bashshar, 2017) performs the functions of linking the cognitive structure of the subject (thinking) with affective structures (feel) related to the subject's behavior, of which the shares are generated (act) both intellectual and emotional subject. "The motivation is always connected with a certain structural level (cognitive). " (Piaget, (1970), cited in Perez, A., 1995, p. 46).

Then, once the motivation as activator and active engine operation cognitive structures, cycles of assimilation and accommodation, and essentially assimilation become acceleration cognition through processes repeat as trend present in assimilation, again induce the subject's interaction with the environment to extract its knowledge that can be incorporated into their cognitive structures.

In conclusion, there is a direct link between the contributions of Cognitive Psychology learning and ICT; analysis of learning theory based on the psychology of Piaget allows clearly identify the structural principles of the Piagetian theory can be applied, evaluate and assess in training processes supported by virtual spaces, and its educational value with pedagogical sense is undeniable possibilities to improve the teaching-learning process conducted in virtual spaces supported by ICT.

\section{The Theory of Cultural-Historical Psychology and ICTs}

The postulates of Vygotsky in their relationship with ICTs without an exhaustive list have been used by: i) Researchers in learning communities eLearning to validate that student learning is increased in relation to the other (Dascalu, Bodea, Lytras, De Pablos, \& Burlacu, 2014), (Marek \& Skrabut, 2017). ii) Assessment system developers focused on eLearning based on the concept of the ZPD ( "Zone of Proximal Development") (Wang, 2014), (Kanjug \& Chaijaroen, 2012). iii) Blended-Learning Researchers applied to education for adults with constructivist approach (Catalano, 2014). iv) Evaluators learning collaborative virtual environments (Yadollahi \& Rahimi, 2015) (Green, Wyllie, \& Jackson, 2014). v) Curriculum Designers Higher Education programs applying constructivist approaches based social learning (Sejzi \& bin Aris, 2012). vi) Modelers eLearning socio-constructivist (EI Mhouti, Nasseh, \& Erradi, 2013). vii) Teachers who use smart learning environments supported by technology, which allows guide students in their curriculum through travel and learning materials in class (Desmarais \& Baker, 2012). viii) Designers learning environments based on web with constructivist approach based on the mental model (Kanjug \& Chaijaroen, 2012). ix) Designers multimedia environments with social and constructivist approach, with collaborative tools and learning model focused on coaching (Samat \& Chaijaroen, 2012). x) Social network analysts to predict the use of the networks mentioned emphasizing the importance of collaborative shares in Facebook (S. K. Sharma, Joshi, \& Sharma, 2016), (Raspopovic, Cvetanovic, Medan, \& Ljubojevic, 2017).

Based on the above educators, eLearning designers and researchers, among others use Vygotsky's theory in eLearning emphasizing the use of collaborative actions for achieving learning, be it individual or group. The investigations if it is true are very important in the processes of virtual education, not formally discussed the concepts of Historical-Cultural Psychology both theoretical concepts and practices, in order to analyze and assess the direct relationship of the Vygotsky postulates the formation processes in virtual 
environments supported by ICT. Therefore, from the aforementioned materialist dialectics postulates are analyzed to find their relationship with the processes of virtual education.

Historical-Cultural Psychology is based on the philosophical conception of materialist dialectics whose fundamental theses are:

a) The essence of consciousness is that the relationship with the external environment appears in man's consciousness through its ideal reflection.

b) The (both practical and theoretical) human activity plays a role in the formation of the human psyche. The material world created by human activity affects the entire development of the human psyche.

c) The activity of man and therefore his psyche has a social character (Petrovski, A (1980, pp. 48-49)), quoted in Montealegre, R., 1992, p. 10).

L. S. Vygotsky raised the fundamental thesis of historical and cultural development of psychic processes. Based on the above ideas, it is interpreted that the core of the subject's consciousness is built on the relationship with the external environment and is not a product of biological development stageist only in recital subject-object.

In the analysis of the ideas of dialectical materialist philosophy conception of psyche that is handled is "a) The psyche is a function ... b) The psyche of man is social, ..." (Montealegre, R., 1992, p. 11). As mental function must be supported in the matter; the matter that supports the intelligence is the brain, and as functional action in the matter is your organization the core of his psyche.

Then, from the mental function in their action of individual organization of the human intellect, society is precisely framed in its history that has allowed the development of man; then his intellect constructed from external activity, requires a bridge of communication so that the activity of the external material enables the operation of the mind in its role of organizing subject intellect, as stated by Vygotsky who argues:

(...) psychics processes, formed on the basis of external activity, material, subject, are influenced by special "instruments", called stimuli-signs that Vygotsky defined as any stimulus artificially created by man that is a means by to which it dominates (assimilates) the conduct or selfemployment. (Vygotsky (1931), cited in Montealegre, R., 1992, p. 12).

The stimuli-signs mentioned by Vygotsky should be interpreted as the "instruments" of communication between the social and historical external material and the material inside the subject's mind. Then "the "stimuli-means" mediate processes "natural" and immediate to be included in behavior as intermediate links; thereby psychic activity (...) becomes. " (Montealegre, R., 1992, p. 12).

The concept of stimuli-signs and stimuli-media as a communication bridge between the material forms of historical and social external activity and internal functional activity in the subject's mind, it is essential to understand the development of the psyche of man ( $D$. Sharma \& Kumar, 2017). Understanding the fact that the mind of the knower in virtual training uses the virtual space as a "tool" for learning, which contains the stimuli-means transforming the mental activity of the student or cause the subject to learn. It is precisely the means, in this case the virtual environment supported by ICTs, those containing the product of historical and social development of mankind; means being signs are in summary language of communication between the subject's mind and society. Language applied in the context of virtual training is a human-technical hybrid; human as a means of communication between beings as rational and technical matters (hardware-hard) than its logical (software) operation allows rational communication with others of their own species using the network. 
Subject's learning achieved in their relationship with the other and with culture, generates cognitive development, and the - development level structures knowledge- achieved by the subject depends on previous experiences. "This involves considering the degree of complexity reached based on previous experiences" (Perez, A., 1995, p. 49); the threshold of complexity of development is related to ICT, in the sense that the functionality of previous brain structures subject, before interacting with the virtual space may be higher, equal or below in relation with the required level within the virtual space in order to navigate, learn and develop. In this sense, the virtual space should assess and evaluate student's previous experiences in order to place he/she at the appropriate point of broad and flexible range of cognitive development.

The aforementioned range, according to the socio-cultural perspective Vygotsky, is the Zone of Proximal Development - Z.P.D., or the gap between what the subject does and what he is capable of doing at a cognitive level.

Vygotsky argued that, in the formation of the concepts of a child, the progress achieved in cooperation with an adult was a much more sensitive indicator of the intellectual abilities of the child. In this context, Vygotsky used the term zo-ped "zone of proximal development": the place where spontaneous concepts of a child, empirically rich but disorganized, "meet" with the systematization and logical reasoning adult. (Vygotsky, L (1995), New edition of the book Thought and Language by Alex Kozulin, p. 25).

The interrelationship of Z.P.D. with ICT is based on the fact that cognitive functional brain structures are built in the Z.P.D. or area of knowledge construction; and this area is influenced by the virtual learning space. The influence that receives the subject of virtual space and affects the construction of their knowledge, is supported on two reasons. The first, in the interindividual situation generated by the virtual space, connectivity and communication are understood in the relationship of the subject with the other, either with the classmates or the teacher responsible for the virtual classroom from whom the subject learns. The second, in the instrumental mediations space of virtual learning, which are computer and communications with its associated technologies of hardware, software and communications that are supporting the staging of pedagogical and didactic theories used in the environment to form the student based on the external activity the subject's mind using the language. For Piaget the single relationship knower object of knowledge, leads to the development of their learning; however, for Vygotsky it is the social interaction that enables the development of learning processes in the subject (Alzahrani, 2017), (Reynolds \& Leeder, 2017).

Then the postulates of the Historic-Cultural Psychology have a direct relationship with ICTs, when applied to the process of eLearning. Student learning through Z.P.D., is enhanced by previous experiences, language, guided activities, communication processes and development related to the socio-cultural environment where it forms the subject apprentice (Kuo, Belland, \& Kuo, 2017). This potential is represented by instrumental communication mediations and contained in the virtual space. These instruments allow in the interaction of the subject with the virtual space to incorporate into the mental structures of the subject the elements present in the culture in order to consolidate a process of construction and maturation of their higher mental functions.

\section{INVESTIGATION METHODOLOGY}

\section{Purpose of the Study and Research Questions}

Given the above theoretical support, the purpose of the research is to validate whether the defining characteristics of the exposed pedagogical theories are met in a set of virtual courses.

Taking into account the purpose of the investigation, the questions that will be solved in the investigation are: 
Question One (Q1): With which of the following theories Behaviorism, Gestalt, Cognitive Psychology, or Historical-Cultural Psychology, is there consistency between the defining characteristics of the theory and the virtual courses analyzed?

Question Two (Q2): Based on the categories that obtain the highest evaluation in the results, how many categories of the 10 best selected (Table: 1) do they validate the consistency between one of the theories (Behaviorism, Gestalt, Cognitive Psychology, or Historical-Cultural Psychology) and the learning process of the virtual course?

The validation of the courses mentioned above, involved the selection of a set of virtual courses. The selection of the courses was made from the e-learning platform identified as MITOPENCOURSEWARE in the Massachusetts Institute of Technology - MIT. These courses were selected because: The MIT has an experience of 15 years in open courses supported by ICT. MIT is the first university in ranking QS World University Rankings $₫$ 2015/16 (http://www.topuniversities.com).

Based on the theory developed, we selected 20 experts in virtual education, in order to validate the defining characteristics of each pedagogical theory. The inclusion criteria for selecting the Virtual Education experts for the research were: i) Graduated professionals in the areas of Education, Psychology, and Teaching in Virtual Spaces supported by TICs. ii) Experience in Virtual Education not less than three years. iii) Finally, selected professionals have as main activity to attend the teaching-virtual learning processes. The experts were in charge of evaluating the courses mentioned on the basis of the defining characteristics of each theory, doing the evaluation of the courses both at a theoretical level and at a practical level. This involved not only the theoretical fulfillment of the course but also the fulfillment of the practical evidence of the virtual course in relation to the defining characteristics mentioned.The defining characteristics of each theory are presented in Table No: 1

Table 1. Defining characteristics of each theory

\begin{tabular}{|c|c|c|c|}
\hline Behaviorism & Gestalt & $\begin{array}{l}\text { Cognitive } \\
\text { Psychology }\end{array}$ & $\begin{array}{l}\text { Historical-Cultural } \\
\text { Psychology }\end{array}$ \\
\hline Stimuli (E) & Organized whole & Adaptation & $\begin{array}{l}\text { Zone of Proximal } \\
\text { Development (Z.P.D.) }\end{array}$ \\
\hline $\begin{array}{l}\text { Answer (R) } \\
\text { Reinforcement (Z) }\end{array}$ & $\begin{array}{l}\text { Synergy } \\
\text { Systemic holistic } \\
\text { Background/shape }\end{array}$ & $\begin{array}{l}\text { Assimilation } \\
\text { Accommodation } \\
\text { Motivation }\end{array}$ & $\begin{array}{l}\text { Language } \\
\text { Guided activities } \\
\text { Social Communication } \\
\text { Socio-cultural } \\
\text { environment }\end{array}$ \\
\hline
\end{tabular}

It stands to reason that the categories mentioned when analyzed in virtual courses are not explicit (for example Z.P.D.). Therefore the above table was transformed by the esperts with categories contained in the virtual course or observable behaviors of students in their learning process.

Behaviorism Theory for the elements to assess are: web page, learning object, images and MicroWorlds (Table No: 3).

In Gestalt: web page, organized whole, synergy, systemic holistic, background motivation derived form / shape, problem solving in function of background / shape, background / shape and perception (Table No. 4).

In the case of Cognitive web page, syllabus, calendar, assimilation, accommodation, adaptation, motivation, theoretical concepts, reading, lectures notes, realated resources (manuals, books application examples), lecture audio, video lectures, problem solving, study of cases, conceptual pedagogy, assignments, demostrations, student games, photos, 
course publicity, study materials, external links, oral presentations, recitations, single class participation, individual projects, blogs, web_site, personal portfolios, course pedagogies, exam, laboratories, simulations, tools, writing exercises (papers) and field trip (Table No. 5).

Historical-Cultural Psychology: web page (stimuli-means), collaborative / cooperative project, constructivist design, team portfolio, team building resources, social constructivism, social networks, stimuli-signs (content), languages, zoped or Zone of Proximal Development (Z.P.D.), virtual tutors, active learning, discussions and presentations, study groups and cooperation (Table No. 6).

The objective of the research is to validate the characteristics associated with the theories mentioned that more are presented in virtual courses at MIT, in order to identify the trend of educational theory most widely used in the teaching-learning process.

The population was 2704 courses. The total number was 29 academic programs. The sample size (n) for each program to estimate population proportions took the statistic:

$$
n=\frac{N p q z^{2}}{(N-1) d^{2}+z^{2} p q}
$$

The statistical variables are: $N$ is the population size of each program; $p(0.5)$, is the population in favor; $q(0.5)$, it is the population against; $d(0.15)$ is the statistical error; $z$ (1.645), is the level of confidence. The total sample was 629 courses.

\section{ANALYSIS OF RESULTS}

The findings respond to the purpose of the study for the following justification reasons:

Question Q1 of the study was to classify a set of virtual courses, in order to identify in them the defining characteristics of theories Behaviorism, Gestalt, Cognitive Psychology, or Historical-Cultural Psychology.

The answers to Q1 are: A total of 629 MIT courses were evaluated. A large total of 8505 responses were obtained. Based on the answers obtained the results corresponding to each of the theories are: Behaviorism Theory for 1471 (17.29\%) were obtained, Gestalt Theory in $2229(26.20 \%)$ in Cognitive Psychology $4246(49.92 \%)$ and Historical-Cultural Psychology 559 (6.57\%).

Question Q2 of the research was based on selecting the 10 best rated categories. The best assessed categories correspond to the highest scoring results in the evaluation of the courses in relation to the theory used in the virtual course or pedagogical approach.

The answers to question Q2 are: For each of the theories the results of each category were added and ordered from highest to lowest. The results by categories are: Behaviorism Theory, the highest category was Images with 596 (Table No. 3). Gestalt Theory, Background / Shape was rated best with 554 (Table No: 4). Cognitive Psychology: Syllabus 577, Language / Theorethical with 495, Assigments with 467, Reading with 454, Lectures Notes with 271, and Papers with 256 (Table No: 5). Finally, in the Historical-Cultural Psychology theory none of its categories were placed in the top 10 of the study.

The integrated results of all categories, which justify the top $\mathbf{1 0}$ evaluated categories from highest to lowest are shown in Table No: 2. 
Table 2. Best evaluated characteristics (10) of each theory

\begin{tabular}{lllll}
\hline No. & Categories & Results & $\%$ & Pedagogical approach \\
\hline 1 & Images & 596 & 7,00 & Behaviorism Theory \\
2 & Syllabus & 577 & 6,78 & Cognitive Psychology \\
3 & Background/Shape & 554 & 6,51 & Gestalt Theory \\
4 & Languaje / Theorethical & 495 & 5,82 & Cognitive Psychology \\
5 & Organized Whole & 474 & 5,57 & Gestalt Theory \\
6 & Assigments & 467 & 5,49 & Cognitive Psychology \\
7 & Readings & 454 & 5,33 & Cognitive Psychology \\
8 & Microworlds & 391 & 4,59 & Behaviorism Theory \\
9 & Lecture Notes & 271 & 3,18 & Cognitive Psychology \\
10 & Papers & 256 & 3,00 & Cognitive Psychology \\
& TOTAL & 8505 & & \\
\hline
\end{tabular}

Then based on the sample evidence (629 courses analyzed in undergraduated level) it can be concluded that the categories that best met in MIT open courses are related to Cognitive Psychology (6/10 categories). This is justified by the use of Syllabus basis of student learning process, supported by a strong theoretical component, which is specified in assignments, readings and lecture notes in order to write research papers.

It is of great importance to note that: Although the main pedagogical approach of MIT's open courseware is based on Cognitive Psychology (Piaget), the process of virtual teaching and learning is also based on images (Behaviorism Theory). This induces the organization of the form and the shape of these images (Gestalt Theory), in order to achieve an organized totality of the virtual course.

\section{THEORETICAL AND PRACTICAL IMPLICATIONS, LIMITATIONS AND FUTURE RESEARCH}

The theoretical and practical implications of the study are: i) The construction of a conceptual framework related to theories of learning Behaviorism, Gestalt, Cognitive Psychology, and the Historic-Cultural Psychology. ii) The analysis of the interrelation between the theories mentioned with the Information Technologies and the Communications - ICT, within the framework of virtual education. iii) The practical application of the postulates of learning theory applied to learning processes in virtual spaces. iv) Practical validation in a population of 2704 virtual courses, with a significant sample having evaluated 620 virtual classes.

The limitations of the study of the study were: i) The difficulty to find a set of open virtual courses. ii) These classes had to show all their activities of the process teaching and virtual learning. iii) The difficulty of evaluating classes in their theories and virtual practices. iv) The limitation that the knowledge areas of Social Sciences, Medicine, Administration, and Engineering have a significant representation of virtual courses.

The continued steps for future research are: To classify the virtual courses supported by TICs of other universities, in order to compare the pedagogical approach used. According to this pedagogical approach, validate the operation of the virtual courses offered. This operation must be validated in the design, construction, operation, and evaluation phases of the virtual courses, in relation to the pedagogical approach used. Validate the activities of the virtual teaching-learning process in its consistency with the pedagogical approach. Finally, compare the classified courses of the different universities, in order to evaluate the learning achieved by the virtual students. 


\section{CONCLUSIONS}

The development of theories supports the process of learning in virtual spaces supported by ICT allows us to conclude applied to MIT open course leads to the conclusion:

There is a strong relationship between the categories of Cognitive Psychology (49.92\%), and the design and teaching used in the teaching-learning process at MIT. This validates the MIT as a top research university worldwide. The validation of the most used pedagogical approach in the MIT is consistent with its research results. This level of research is justified by: i) According to the international QS ranking, MIT is the world's top university in research in 2015/2016 (Dobrota, Bulajic, Bornmann, \& Jeremic, 2016). ii) Additionally, and taking into account that MIT was ranked in the top position for four consecutive years, the Institute ranked first in 11 of the 36 disciplines on its research record. Of the 11 mentioned disciplines, six correspond to Engineering and Technology; These are: "Architecture, Computer Science, Chemical Engineering, Civil and Structural Engineering, Electrical and Electyronic Engineering, finally Mechanical Engineering, Aeronautics, and Manufacturing". iii) It should be taken into account that the QS ranking is based on the quality of the research, the level achieved by the graduates obtaining employment, the high quality of teaching, and the overall evaluation of the university's constituents, among which Are both students and teachers.

Approaches Gestalt Theory, Behaviorism Theory and Historical-Cultural Psychology are not as used at MIT. However, the use of micro-worlds and images using form and substance and are presented as organized wholes are present in the process of formation of MIT courses.

In Historical-Cultural Pedagogy most used categories are discussions with $22 \%$ (forums), followed by the support of virtual tutors $(13.77 \%)$ in order to make Constructivist designs or run cooperative projects in groups students by $12.16 \%$, where the learning process is done with the other.

\section{BIODATA and CONTACT ADDRESS of AUTHOR}

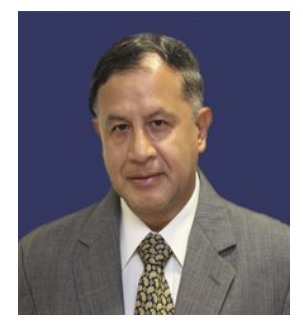

Jose CAPACHO is an assistant professor at the Universidad del Norte (Barranquilla , Colombia). He did his doctoral studies at the University of Salamanca (2008) (Spain), in Learning Processes in Virtual Spaces. Professor Capacho earned his Master studies in Education at the Pontificia Universidad Javeriana (Colombia, 1996). His undergraduate was made in Systems Engineering in the Universidad Industrial de Santander - UIS (Colombia, 1982). Professor has over 30 years of service at Universidad del Norte. During this time, as Coordinator of the System Program, he has led projects of National and International Accreditation of the System Program (Universidad del Norte), with institutions such as the Colombian National Accreditation Council (NAC) (1998,2005,2012); and the Agency Accreditation Board for Engineering and Technolgy $(2003,2005)$. As a teacher he has participated in the renewal accreditation process of the System Program with ABET Accreditation International (2013, 2014, 2015).

\section{Jose CAPACHO}

University del Norte, Barranquilla, COLOMBIA

Phone: 573509379

Email: jcapacho@uninorte.edu.co 


\section{REFERENCES}

Alzaghoul, A. F. (2012). The implication of the learning theories on implementing e-learning courses. The Research Bulletin of Jordan ACM, 11(11), 27-30.

Alzahrani, M. G. (2017). The Effect of Using Online Discussion Forums on Students' Learning. Turkish Online Journal of Educational Technology, 16(1), 164.

Anaya, A. R., Luque, M., \& Peinado, M. (2016). A visual recommender tool in a collaborative learning experience. Expert Systems with Applications, 45, 248-259.

Angelis, Y. (2017). E-learning with Impact: the Role of Narrative Structures and Methods in Designing and Delivering E-learning in a Corporate Environment. En Beyond Storytelling (pp. 303-332). Springer.

Bashshar, C. E. (2017). Virtual Learning Environments' Impact on Adult Learners' Motivation in the Workplace. Walden University.

Burden, K., Aubusson, P., Brindley, S., \& Schuck, S. (2016). Changing knowledge, changing technology: implications for teacher education futures. Journal of Education for Teaching, 42(1), 4-16.

Catalano, H. (2014). The Opportunity of Blended-learning Training Programs in Adult Education-Ascertaining Study. Procedia-Social and Behavioral Sciences, 142, 762768.

Chua, B. L., Liu, W. C., \& Tan, O.-S. (2015). Pedagogical Interfaces in a Problem-Based Learning Environment: Cognitive Functioning at PBL Stages. En Authentic Problem Solving and Learning in the 21st Century (pp. 115-131). Springer.

Chung, S.-M., \& Wu, C.-T. (2017). Designing Music Games and Mobile Apps for Early Music Learning. En Serious Games and Edutainment Applications (pp. 57-75). Springer.

Dascalu, M.-I., Bodea, C.-N., Lytras, M., De Pablos, P. O., \& Burlacu, A. (2014). Improving elearning communities through optimal composition of multidisciplinary learning groups. Computers in Human Behavior, 30, 362-371.

Desmarais, M. C., \& Baker, R. S. (2012). A review of recent advances in learner and skill modeling in intelligent learning environments. User Modeling and User-Adapted Interaction, 22(1-2), 9-38.

Dobrota, M., Bulajic, M., Bornmann, L., \& Jeremic, V. (2016). A new approach to the QS university ranking using the composite I-distance indicator: Uncertainty and sensitivity analyses. Journal of the Association for Information Science and Technology, 67(1), 200-211.

El Mhouti, A., Nasseh, A., \& Erradi, M. (2013). A Socio-constructivist Model of Development of Learning Content in an e-learning Platform Oriented to Management of Academic Knowledge. En E-Learn World Conference on E-Learning in Corporate, Government, Healthcare, and Higher Education, Las Vegas, United States, Page.

Evgeniou, E., \& Loizou, P. (2012). The theoretical base of e-learning and its role in surgical education. Journal of surgical education, 69(5), 665-669.

Farhan, M., Aslam, M., Jabbar, S., Khalid, S., \& Kim, M. (2017). Real-time imaging-based assessment model for improving teaching performance and student experience in elearning. Journal of Real-Time Image Processing, 1-14.

Flavell, J. (1998). The evolutionary psychology of Jean Piaget. Mexico: Editorial Paidos Mexicana S. A..

Gebremeskel, G. B., Kebede, A. A., \& Chai, Y. (2016). The paradigm role of ICT for behavioral and educational psychology: The case of developing countries. International Journal of Information and Education Technology, 6(4), 301.

Gonzalez Guerrero, K., \& Ojeda, C. E. (2013). Caracterizacion de modelos pedagogicos en formacion e-learning. Revista Virtual Universidad Catolica del Norte, 2(39), 4-16. 
Green, J., Wyllie, A., \& Jackson, D. (2014). Virtual worlds: A new frontier for nurse education? Collegian, 21(2), 135-141.

Hilgard, E. Bower, G. (1973). Learning Theories. Mexico, D.F., Mexico: Editorial Trillas, S. A..

Hu, R., Wu, Y.-Y., \& Shieh, C.-J. (2016). Effects of Virtual Reality Integrated Creative Thinking Instruction on Students' Creative Thinking Abilities. Eurasia Journal of Mathematics, Science \& Technology Education, 12(3), 477-486.

Hussain, F. (2012). E-Learning 3.0 = E-Learning 2.0+ Web 3.0?. International Association for Development of the Information Society.

Jovanovic, M., Vukicevic, M., Milovanovic, M., \& Minovic, M. (2012). Using data mining on student behavior and cognitive style data for improving e-learning systems: a case study. International Journal of Computational Intelligence Systems, 5(3), 597-610.

Kanjug, I., \& Chaijaroen, S. (2012). The design of web-based learning environments enhancing mental model construction. Procedia-Social and Behavioral Sciences, 46, 3134-3140.

Kläre, C. (2017). Quantitative information literacy: Designing an online course at the interface between information literacy and statistical literacy. o-bib. Das offene Bibliotheksjournal/herausgegeben vom VDB, 4(1), 117-131.

Klašnja-Milićević, A., Vesin, B., Ivanović, M., Budimac, Z., \& Jain, L. C. (2017). Agents in ELearning Environments. En E-Learning Systems (pp. 43-49). Springer.

Kozulin, A. (1995). Introduction. En: Vygosstky L., Thought, learning, teaching. Wilmington, Delaware (Estados Unidos de America): Addison-Wesley.

Kuo, Y.-C., Belland, B. R., \& Kuo, Y.-T. (2017). Learning through Blogging: Students' Perspectives in Collaborative Blog-Enhanced Learning Communities. Journal of Educational Technology \& Society, 20(2), 37-50.

Lopez, R. E. O., Morales, M. G. E., Hedlefs, A. M. I., \& Gonzalez, T. C. J. (2014). New empirical directions to evaluate online learning. International Journal of Advances in Psychology, 3(2), 40-47.

Lawrence, T. (2005). Taxonomy for the Technology Domain. London, United Kingdom: Editorial Information Science Publishing (an imprint of Idea Group Inc.).

Marek, M. W., \& Skrabut, S. (2017). Privacy in Educational use of Social Media in the US. The journal, 16(3).

Montealegre, R. (1992). Vygotsky and the conception of language. Santafe de Bogota D. C. Colombia: Research Committee for Scientific - CINDEC National University Colombia.

Nawaz, A., \& Kundi, G. M. (2010). From objectivism to social constructivism: The impacts of information and communication technologies (ICTs) on higher education. International Journal of Science and Technology Education Research, 1(2).

Ninaus, M., Kober, S. E., Friedrich, E. V., Dunwell, I., De Freitas, S., Arnab, S., ... Louchart, S. (2014). Neurophysiological methods for monitoring brain activity in serious games and virtual environments: a review. International Journal of Technology Enhanced Learning, 6(1), 78-103.

Paraskeva, F., Mysirlaki, S., \& Papagianni, A. (2010). Multiplayer online games as educational tools: Facing new challenges in learning. Computers \& Education, 54(2), 498-505.

Perez, A. (1995). The teaching-learning processes: didactic analysis of the main theories of learning. En J. Gimeno, y Perez, A. Understand and transform teaching, (pp. 34-62). Madrid, España: Editions Morata, S. L.

Pressman, R. (2006). Software Engineering. A practical approach. Mexico D. F.: The MaGrawHill Interamericana.

QUTECHATE, W., Almarabeh, T., \& Alfayez, R. (2014). E-LEARNING SYSTEM IN THE UNIVERSITY OF JORDAN: PROBLEM SOLVING CASE STUDY. Journal of Theoretical \& Applied Information Technology, 65(1). 
Railean, E. (2017). Metacognition in Higher Education: Successful Learning Strategies. Metacognition and Successful Learning Strategies in Higher Education, 1.

Railean, E. A. (2017). Teacher-Centered Versus Learner-Centered Design of Screen. En User Interface Design of Digital Textbooks (pp. 59-80). Springer.

Raspopovic, M., Cvetanovic, S., Medan, I., \& Ljubojevic, D. (2017). The Effects of Integrating Social Learning Environment with Online Learning. The International Review of Research in Open and Distributed Learning, 18(1).

Reynolds, R., \& Leeder, C. (2017). Information Uses and Learning Outcomes During Guided Discovery in a Blended E-Learning Game Design Program for Secondary Computer Science Education. En Proceedings of the 50th Hawaii International Conference on System Sciences.

Romero, C., \& Ventura, S. (2013). Data mining in education. Wiley Interdisciplinary Reviews: Data Mining and Knowledge Discovery, 3(1), 12-27.

Samat, C., \& Chaijaroen, S. (2012). Design and development of constructivist multimedia learning environment to enhance computer skills for computer education learners. Procedia-Social and Behavioral Sciences, 46, 3000-3005.

Sejzi, A. A., \& bin Aris, B. (2012). Constructivist Approach in Virtual Universities. ProcediaSocial and Behavioral Sciences, 56, 426-431.

Sethy, S. S. (2012). Cognitive skills: A modest way of learning through technology. Turkish Online Journal of Distance Education, 13(3).

Sharma, D., \& Kumar, V. (2017). A Framework for Collaborative and Convenient Learning on Cloud Computing Platforms. International Journal of Web-Based Learning and Teaching Technologies (IJWLTT), 12(2), 1-20.

Sharma, S. K., Joshi, A., \& Sharma, H. (2016). A multi-analytical approach to predict the Facebook usage in higher education. Computers in Human Behavior, 55, 340-353.

Schunk, D. (1997). Learning Theories, Mexico: Prentice-Hall Hispanoamericana, S. A..

Slavík, J., Janík, T., \& Najvar, P. (2017). Producing knowledge for improvement: the 3A procedure as a tool for research on teaching and learning. Pedagogika, 66(6).

Tettegah, S., McCreery, M., \& Blumberg, F. (2015). Toward a Framework for Learning and Digital Games Research. Taylor \& Francis.

Thompson, N., \& McGill, T. J. (2013). The application of affective computing technology to elearning. Pedagogical Considerations and Opportunities for Teaching and Learning on the Web, 109.

Wang, T.-H. (2014). Developing an assessment-centered e-Learning system for improving student learning effectiveness. Computers \& Education, 73, 189-203.

Winterhalder, J. (2017). Teachers' Perceptions and Experiences in Implementing Mobile Devices Into Their Teaching. Walden University.

Yadollahi, H., \& Rahimi, A. (2015). The Effects of Different Task Types on Learners' Performance in Collaborative Virtual Learning Environment. Procedia-Social and Behavioral Sciences, 192, 526-533.

Yang, T.-C., Hwang, G.-J., \& Yang, S. J.-H. (2013). Development of an Adaptive Learning System with Multiple Perspectives based on Students? Learning Styles and Cognitive Styles. Educational Technology \& Society, 16(4), 185-200.

Yildirim, I. (2017). The effects of gamification-based teaching practices on student achievement and students' attitudes toward lessons. The Internet and Higher Education, 33, 86-92. 


\section{APPENDICES}

Appendix A: Categories Considered in the Behaviorism Theory

\begin{tabular}{|c|c|c|c|c|c|c|c|c|c|c|c|}
\hline & & & & & \multicolumn{7}{|c|}{ Behaviorism Theory } \\
\hline No. & Program & $\mathrm{N}$ & $\mathrm{n}$ & Level & $\begin{array}{l}\text { Web } \\
\text { Page }\end{array}$ & $\begin{array}{l}\text { Learning } \\
\text { object }\end{array}$ & Images & MicroWorls & $\begin{array}{l}\text { Stimuli } \\
(E)\end{array}$ & $\begin{array}{l}\text { Anscer } \\
(\mathrm{R})\end{array}$ & $\begin{array}{c}\text { Reinforcement } \\
(\mathrm{z})\end{array}$ \\
\hline 1 & $\begin{array}{l}\text { Aeronautics and } \\
\text { Astronautics }\end{array}$ & 79 & 22 & $\mathrm{U}$ & 22 & 20 & 22 & 11 & 3 & 3 & 1 \\
\hline 2 & Architecture & 104 & 24 & U & 24 & 14 & 24 & 17 & 6 & 6 & 1 \\
\hline 3 & Biological Engineering & 40 & 18 & U & 18 & 10 & 18 & 13 & 5 & 5 & 3 \\
\hline 4 & Biology & 111 & 24 & $\mathrm{U}$ & 24 & 10 & 23 & 13 & 3 & 3 & 2 \\
\hline 5 & $\begin{array}{l}\text { Brain and Cognitive } \\
\text { Sciences }\end{array}$ & 87 & 23 & U & 23 & 18 & 21 & 11 & 7 & 6 & 5 \\
\hline 6 & Chemical Engineering & 45 & 18 & U & 18 & 14 & 18 & 15 & 7 & 7 & 6 \\
\hline 7 & Chemistry & 47 & 18 & U & 18 & 7 & 18 & 9 & 1 & 1 & 0 \\
\hline 8 & $\begin{array}{l}\text { Civil and Environmental } \\
\text { Engineering }\end{array}$ & 98 & 23 & U & 23 & 12 & 22 & 17 & 2 & 2 & 1 \\
\hline 9 & $\begin{array}{l}\text { Comparative Media } \\
\text { Studies/Writing }\end{array}$ & 112 & 24 & U & 24 & 5 & 24 & 13 & 0 & 0 & 0 \\
\hline 10 & $\begin{array}{l}\text { Earth, Atmospheric, and } \\
\text { Planetary Sciences }\end{array}$ & 100 & 23 & U & 23 & 13 & 22 & 19 & 2 & 12 & 0 \\
\hline 11 & Economics & 82 & 22 & U & 22 & 22 & 3 & 20 & 18 & 1 & 1 \\
\hline 12 & $\begin{array}{l}\text { Electrical Engineering and } \\
\text { Computer Science }\end{array}$ & 246 & 27 & U & 27 & 22 & 25 & 16 & 4 & 4 & 3 \\
\hline 13 & $\begin{array}{l}\text { Engineering Systems } \\
\text { Division }\end{array}$ & 87 & 23 & U & 23 & 17 & 23 & 19 & 1 & 1 & 0 \\
\hline 14 & Experimental Study Group & 30 & 15 & $\mathrm{U}$ & 15 & 3 & 15 & 6 & 2 & 2 & 2 \\
\hline 15 & $\begin{array}{l}\text { Global Studies and } \\
\text { Languages }\end{array}$ & 101 & 24 & U & 24 & 1 & 23 & 12 & 1 & 1 & 0 \\
\hline 16 & $\begin{array}{l}\text { Health Sciences and } \\
\text { Technology }\end{array}$ & 72 & 22 & U & 22 & 2 & 22 & 10 & 0 & 0 & 0 \\
\hline 17 & Linguistics and Philosophy & 86 & 23 & U & 23 & 6 & 22 & 13 & 4 & 4 & 2 \\
\hline 18 & Literature & 118 & 24 & U & 24 & 6 & 24 & 13 & 3 & 3 & 2 \\
\hline 19 & $\begin{array}{l}\text { Materials Science and } \\
\text { Engineering }\end{array}$ & 57 & 20 & U & 20 & 7 & 20 & 15 & 3 & 3 & 3 \\
\hline 20 & Mathematics & 165 & 26 & U & 26 & 18 & 24 & 13 & 0 & 0 & 0 \\
\hline 21 & Mechanical Engineering & 140 & 25 & $\mathrm{U}$ & 25 & 13 & 24 & 15 & 0 & 0 & 0 \\
\hline 22 & Media Arts and Sciences & 41 & 18 & U & 18 & 11 & 18 & 12 & 2 & 1 & 0 \\
\hline 23 & Music and Theater Arts & 62 & 20 & U & 20 & 5 & 19 & 11 & 0 & 0 & 0 \\
\hline 24 & $\begin{array}{l}\text { Nuclear Science and } \\
\text { Engineering }\end{array}$ & 78 & 22 & U & 22 & 10 & 22 & 13 & 0 & 0 & 0 \\
\hline 25 & Political Science & 117 & 24 & U & 24 & 5 & 24 & 15 & 2 & 1 & 0 \\
\hline 26 & $\begin{array}{l}\text { Science, Technology, and } \\
\text { Society }\end{array}$ & 173 & 26 & U & 26 & 13 & 26 & 20 & 3 & 3 & 0 \\
\hline 27 & Urban Studies and Planning & 168 & 26 & U & 26 & 6 & 26 & 20 & 3 & 3 & 2 \\
\hline 28 & $\begin{array}{l}\text { Women's and Gender } \\
\text { Studies }\end{array}$ & 51 & 19 & U & 19 & 4 & 18 & 9 & 1 & 1 & 0 \\
\hline 29 & $\begin{array}{l}\text { Writing and Humanistic } \\
\text { Studies }\end{array}$ & 7 & 6 & U & 6 & 0 & 6 & 1 & 0 & 0 & 0 \\
\hline & & 2704 & 629 & & 629 & 294 & 596 & 391 & 83 & 73 & 34 \\
\hline
\end{tabular}


Appendix B: Categories considered in the Gestalt Theory

\begin{tabular}{|c|c|c|c|c|c|c|c|c|c|c|c|}
\hline \multirow[b]{2}{*}{ No. } & \multirow[b]{2}{*}{ Program } & \multirow[b]{2}{*}{$\mathrm{N}$} & \multirow[b]{2}{*}{$\mathrm{n}$} & \multirow[b]{2}{*}{ Level } & \multicolumn{7}{|c|}{ Gestalt Theory } \\
\hline & & & & & $\begin{array}{c}\text { Organize } \\
\text { Whole }\end{array}$ & Synergy & $\begin{array}{c}\text { Systemic } \\
\text { Holistic }\end{array}$ & Motivation & $\mathrm{P}$ & $\begin{array}{l}\text { Background } \\
\text { / Shape }\end{array}$ & Perception \\
\hline 1 & $\begin{array}{l}\text { Aeronautics and } \\
\text { Astronautics }\end{array}$ & 79 & 22 & U & 11 & 5 & 9 & 7 & 8 & 10 & 7 \\
\hline 2 & Architecture & 104 & 24 & U & 20 & 6 & 17 & 11 & 11 & 21 & 13 \\
\hline 3 & Biological Engineering & 40 & 18 & $U$ & 12 & 8 & 8 & 13 & 17 & 12 & 8 \\
\hline 4 & Biology & 111 & 24 & U & 20 & 6 & 8 & 5 & 14 & 21 & 7 \\
\hline 5 & $\begin{array}{l}\text { Brain and Cognitive } \\
\text { Sciences }\end{array}$ & 87 & 23 & U & 8 & 4 & 6 & 3 & 3 & 6 & 5 \\
\hline 6 & Chemical Engineering & 45 & 18 & U & 18 & 7 & 12 & 12 & 14 & 14 & 6 \\
\hline 7 & Chemistry & 47 & 18 & U & 16 & 2 & 5 & 4 & 9 & 11 & 3 \\
\hline 8 & $\begin{array}{l}\text { Civil and Environmental } \\
\text { Engineering }\end{array}$ & 98 & 23 & U & 22 & 5 & 8 & 8 & 20 & 21 & 7 \\
\hline 9 & $\begin{array}{l}\text { Comparative Media } \\
\text { Studies/Writing }\end{array}$ & 112 & 24 & $U$ & 15 & 6 & 8 & 12 & 10 & 24 & 13 \\
\hline 10 & $\begin{array}{l}\text { Earth, Atmospheric, and } \\
\text { Planetary Sciences }\end{array}$ & 100 & 23 & $U$ & 19 & 10 & 14 & 12 & 20 & 21 & 12 \\
\hline 11 & Economics & 82 & 22 & U & 0 & 15 & 5 & 7 & 7 & 15 & 18 \\
\hline 12 & $\begin{array}{l}\text { Electrical Engineering and } \\
\text { Computer Science }\end{array}$ & 246 & 27 & U & 14 & 7 & 7 & 11 & 26 & 24 & 12 \\
\hline 13 & $\begin{array}{l}\text { Engineering Systems } \\
\text { Division }\end{array}$ & 87 & 23 & U & 22 & 8 & 12 & 14 & 21 & 21 & 9 \\
\hline 14 & Experimental Study Group & 30 & 15 & $U$ & 9 & 2 & 3 & 4 & 9 & 15 & 4 \\
\hline 15 & $\begin{array}{l}\text { Global Studies and } \\
\text { Languages }\end{array}$ & 101 & 24 & $U$ & 15 & 1 & 5 & 4 & 9 & 24 & 2 \\
\hline 16 & $\begin{array}{l}\text { Health Sciences and } \\
\text { Technology }\end{array}$ & 72 & 22 & $\mathrm{U}$ & 15 & 3 & 5 & 7 & 14 & 19 & 4 \\
\hline 17 & Linguistics and Philosophy & 86 & 23 & U & 8 & 6 & 7 & 6 & 10 & 22 & 8 \\
\hline 18 & Literature & 118 & 24 & $U$ & 18 & 6 & 10 & 8 & 7 & 25 & 14 \\
\hline 19 & $\begin{array}{l}\text { Materials Science and } \\
\text { Engineering }\end{array}$ & 57 & 20 & $U$ & 13 & 5 & 6 & 5 & 15 & 19 & 5 \\
\hline 20 & Mathematics & 165 & 26 & $U$ & 24 & 7 & 7 & 8 & 23 & 24 & 11 \\
\hline 21 & Mechanical Engineering & 140 & 25 & $\mathrm{U}$ & 21 & 8 & 9 & 9 & 23 & 25 & 15 \\
\hline 22 & Media Arts and Sciences & 41 & 18 & $U$ & 16 & 5 & 8 & 7 & 12 & 18 & 9 \\
\hline 23 & Music and Theater Arts & 62 & 20 & $\mathrm{U}$ & 18 & 6 & 6 & 7 & 10 & 20 & 11 \\
\hline 24 & $\begin{array}{l}\text { Nuclear Science and } \\
\text { Engineering }\end{array}$ & 78 & 22 & $U$ & 22 & 8 & 8 & 9 & 22 & 21 & 8 \\
\hline 25 & Political Science & 117 & 24 & $U$ & 23 & 3 & 7 & 6 & 6 & 24 & 5 \\
\hline 26 & $\begin{array}{l}\text { Science, Technology, and } \\
\text { Society }\end{array}$ & 173 & 26 & $U$ & 26 & 5 & 5 & 7 & 17 & 26 & 6 \\
\hline 27 & Urban Studies and Planning & 168 & 26 & U & 26 & 5 & 8 & 6 & 12 & 26 & 8 \\
\hline 28 & $\begin{array}{l}\text { Women's and Gender } \\
\text { Studies }\end{array}$ & 51 & 19 & $U$ & 18 & 1 & 2 & 3 & 4 & 19 & 2 \\
\hline \multirow[t]{2}{*}{29} & $\begin{array}{l}\text { Writing and Humanistic } \\
\text { Studies }\end{array}$ & 7 & 6 & $U$ & 5 & 0 & 1 & 1 & 2 & 6 & 2 \\
\hline & & 2704 & 629 & & 474 & 160 & 216 & 216 & 375 & 554 & 234 \\
\hline
\end{tabular}


Appendix C: Categories Considered in the Cognitive Theory

\begin{tabular}{|c|c|c|c|c|c|c|c|c|c|c|c|c|c|c|c|c|c|c|c|c|c|c|c|c|c|c|c|c|c|c|c|c|c|c|c|c|c|c|c|c|}
\hline & & & & & \multicolumn{36}{|c|}{ Cognitive Psychology } \\
\hline No. & Program & $\mathrm{N}$ & $n$ & $\overline{\mathrm{g}}$ & 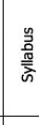 & 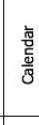 & 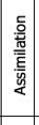 & 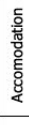 & 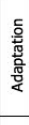 & 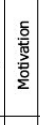 & 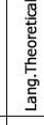 & 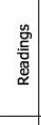 & & 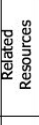 & 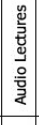 & 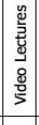 & 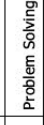 & 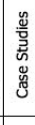 & 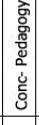 & 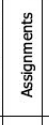 & 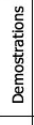 & 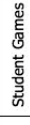 & 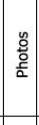 & 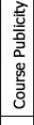 & 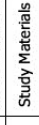 & 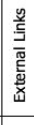 & 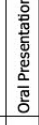 & 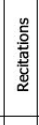 & 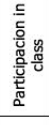 & 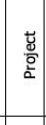 & 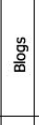 & $\begin{array}{l}\frac{w}{w} \\
w_{1} \\
0 \\
3 \\
3\end{array}$ & 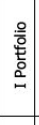 & 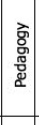 & 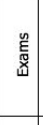 & 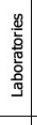 & 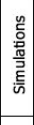 & $\frac{n}{\circ}$ & 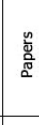 & 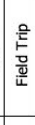 \\
\hline 1 & \begin{tabular}{|l|} 
Aeronautics and \\
Astronautics
\end{tabular} & 79 & 22 & u & 14 & 10 & 1 & 1 & 1 & 1 & 8 & 6 & 12 & 3 & 0 & 1 & 16 & 0 & 7 & 13 & 0 & 0 & 0 & 0 & 0 & 0 & 1 & 0 & 0 & 5 & 0 & 0 & 0 & 2 & 10 & 0 & 0 & 0 & 2 & 0 \\
\hline 2 & Architecture & 104 & 24 & $u$ & 23 & 19 & 0 & 0 & 0 & 0 & 11 & 14 & 5 & 1 & 0 & 1 & 6 & 0 & 0 & 15 & 0 & 0 & 0 & 0 & 1 & 0 & 3 & 0 & 2 & 20 & 0 & 0 & 0 & 0 & 1 & 0 & 0 & 0 & 3 & 0 \\
\hline 3 & \begin{tabular}{|l|} 
Biological \\
Engineering
\end{tabular} & 40 & 18 & $u$ & 18 & 9 & 0 & 0 & 0 & 0 & 11 & 9 & 13 & 7 & 0 & 1 & 7 & 0 & 0 & 16 & 0 & 0 & 0 & 0 & 0 & 0 & 0 & 1 & 0 & 5 & 0 & 0 & 0 & 0 & 9 & 0 & 1 & 3 & 4 & 0 \\
\hline 4 & Biology & 111 & 24 & $u$ & 24 & 19 & 0 & 0 & 0 & 0 & 20 & 17 & 7 & 10 & 1 & 5 & 12 & 0 & 0 & 17 & 0 & 0 & 0 & 0 & 5 & 0 & 6 & 5 & 0 & 1 & 0 & 0 & 0 & 1 & 15 & 2 & 0 & 0 & 8 & 1 \\
\hline 5 & \begin{tabular}{|l|} 
Brain and \\
Cognitive \\
Sciences
\end{tabular} & 87 & 23 & u & 11 & 8 & 3 & 3 & 3 & 0 & 14 & 9 & 6 & 4 & 1 & 0 & 5 & 0 & 3 & 15 & 0 & 0 & 0 & 0 & 4 & 3 & 8 & 0 & 1 & 5 & 0 & 0 & 0 & 0 & 11 & 0 & 0 & 0 & 11 & 0 \\
\hline 6 & \begin{tabular}{|l} 
Chemical \\
Engineering
\end{tabular} & 45 & 18 & U & 18 & 13 & 0 & 0 & 0 & 1 & 12 & 10 & 8 & 5 & 0 & 1 & 15 & 0 & 0 & 15 & 0 & 0 & 0 & 0 & 0 & 0 & 1 & 3 & 0 & 4 & 0 & 0 & 0 & 0 & 9 & 0 & 0 & 3 & 6 & 0 \\
\hline 7 & Chemistry & 47 & 18 & u & 18 & 13 & 0 & 0 & 0 & 0 & 7 & 8 & 11 & 5 & 0 & 2 & 11 & 0 & 1 & 6 & 0 & 0 & 0 & 0 & 0 & 0 & 0 & 3 & 0 & 1 & 0 & 0 & 0 & 0 & 11 & 0 & 0 & 0 & 1 & 0 \\
\hline 8 & \begin{tabular}{|l} 
Civil and \\
Environmental \\
Engineering \\
\end{tabular} & 98 & 23 & u & 23 & 17 & 0 & 0 & 0 & 1 & 18 & 16 & 14 & 7 & 1 & 3 & 12 & 0 & 0 & 16 & 0 & 0 & 0 & 0 & 1 & 0 & 3 & 4 & 0 & 5 & 0 & 0 & 0 & 1 & 16 & 0 & 0 & 3 & 1 & 0 \\
\hline 9 & $\begin{array}{l}\text { Comparative } \\
\text { Media } \\
\text { Studies/Writing }\end{array}$ & 112 & 24 & u & 24 & 22 & 0 & 0 & 0 & 0 & 19 & 21 & 0 & 13 & 0 & 0 & 0 & 0 & 0 & 23 & 0 & 0 & 0 & 0 & 0 & 0 & 6 & 0 & 2 & 2 & 0 & 0 & 3 & 0 & 0 & 0 & 0 & 0 & 22 & 0 \\
\hline 10 & $\begin{array}{l}\text { Earth, } \\
\text { Atmospheric, } \\
\text { and Planetary } \\
\text { Sciences }\end{array}$ & 100 & 23 & u & 22 & 14 & 1 & 0 & 0 & 0 & 20 & 13 & 13 & 8 & 0 & 0 & 14 & 0 & 0 & 16 & 0 & 0 & 0 & 0 & 2 & 0 & 2 & 0 & 0 & 10 & 0 & 3 & 0 & 0 & 6 & 0 & 0 & 2 & 7 & 1 \\
\hline 11 & Economics & 82 & 22 & u & 0 & 22 & 17 & 0 & 0 & 0 & 0 & 22 & 21 & 13 & 0 & 0 & 0 & 18 & 0 & 0 & 20 & 0 & 0 & 0 & 0 & 2 & 0 & 2 & 3 & 0 & 1 & 0 & 0 & 0 & 0 & 17 & 0 & 0 & 0 & 3 \\
\hline 12 & $\begin{array}{l}\text { Electrical } \\
\text { Engineering and } \\
\text { Computer } \\
\text { Science } \\
\end{array}$ & 246 & 27 & u & 27 & 21 & 0 & 0 & 0 & 0 & 26 & 16 & 16 & 12 & 1 & 12 & 22 & 0 & 1 & 21 & & 0 & 0 & 0 & 0 & 0 & 0 & 6 & 0 & 8 & 0 & 0 & 0 & 3 & 19 & 9 & 2 & 6 & 3 & 0 \\
\hline 13 & \begin{tabular}{|l} 
Engineering \\
Systems Division
\end{tabular} & 87 & 23 & u & 23 & 13 & 0 & 0 & 0 & 0 & 20 & 17 & 16 & 4 & 0 & 4 & 12 & 0 & 0 & 18 & 0 & 0 & 0 & 0 & 0 & 0 & 4 & 1 & 0 & 10 & 0 & 0 & 0 & 0 & 5 & 0 & 0 & 0 & 7 & 0 \\
\hline 14 & \begin{tabular}{|l} 
Experimental \\
Study Group
\end{tabular} & 30 & 15 & U & 13 & 10 & 0 & 0 & 0 & 0 & 15 & 13 & 4 & 5 & 0 & 1 & 1 & 0 & 0 & 6 & 0 & 0 & 0 & 0 & 0 & 0 & 0 & 0 & 0 & 6 & 0 & 0 & 0 & 0 & 0 & 0 & 0 & 0 & 4 & 0 \\
\hline 15 & $\begin{array}{l}\text { Global Studies } \\
\text { and Languages }\end{array}$ & 101 & 24 & u & 24 & 17 & 0 & 0 & 0 & 0 & 23 & 23 & 5 & 6 & 0 & 2 & 4 & 0 & 0 & 22 & 0 & 0 & 0 & 0 & 3 & 0 & 3 & 0 & 0 & 3 & 1 & 1 & 0 & 0 & 0 & 0 & 0 & 0 & 17 & 0 \\
\hline 16 & $\begin{array}{l}\text { Health Sciences } \\
\text { and Technology }\end{array}$ & 72 & 22 & u & 21 & 11 & 0 & 0 & 0 & 0 & 20 & 19 & 3 & 5 & 0 & 1 & 1 & 0 & 0 & 18 & 0 & 0 & 0 & 0 & 3 & 0 & 0 & 0 & 0 & 1 & 0 & 2 & 0 & 0 & 1 & 0 & 0 & 0 & 19 & 0 \\
\hline 17 & $\begin{array}{l}\text { Linguistics and } \\
\text { Philosophy }\end{array}$ & 86 & 23 & u & 22 & 16 & 0 & 0 & 0 & 0 & 22 & 21 & 12 & 6 & 0 & 4 & 6 & 0 & 0 & 20 & 0 & 0 & 0 & 0 & 4 & 1 & 4 & 4 & 0 & 0 & 0 & 0 & 0 & 0 & 5 & 0 & 0 & 0 & 20 & 0 \\
\hline 18 & & 118 & 24 & u & 25 & 9 & 0 & 0 & 0 & 0 & 21 & 21 & 0 & 6 & 0 & 1 & 0 & 0 & 0 & 21 & 0 & 0 & 0 & 0 & 1 & 0 & 6 & 0 & 6 & 1 & 0 & 0 & 0 & 0 & 2 & 0 & 0 & 0 & 21 & 0 \\
\hline 19 & $\begin{array}{l}\text { Materials Science } \\
\text { and Engineering }\end{array}$ & 57 & 20 & $\mathrm{u}$ & 20 & 11 & 0 & 0 & 0 & 0 & 10 & 10 & 11 & 4 & 0 & 1 & 11 & 0 & 0 & 14 & 0 & 0 & 0 & 0 & 3 & 0 & 0 & 4 & 0 & 4 & 0 & 0 & 0 & 0 & 10 & 5 & 0 & 2 & 5 & 0 \\
\hline 20 & Mathematics & 165 & 26 & U & 23 & 17 & 0 & 0 & 0 & 0 & 23 & 20 & 15 & 9 & 0 & 5 & 19 & 0 & 0 & 20 & 8 & 2 & 0 & 0 & 8 & 0 & 1 & 5 & 0 & 2 & 0 & 0 & 0 & 0 & 20 & 2 & 0 & 4 & 3 & 0 \\
\hline 21 & \begin{tabular}{|l} 
Mechanical \\
Engineering
\end{tabular} & 140 & 25 & $\mathrm{u}$ & 25 & 18 & 0 & 0 & 0 & 0 & 23 & 16 & 11 & 10 & 0 & 1 & 20 & 0 & 0 & 20 & 2 & 1 & 0 & 0 & 6 & 0 & 0 & 3 & 0 & 5 & 0 & 0 & 0 & 0 & 14 & 12 & 1 & 6 & 6 & 0 \\
\hline 22 & $\begin{array}{l}\text { Media Arts and } \\
\text { Sciences }\end{array}$ & 41 & 18 & u & 18 & 9 & 0 & 0 & 0 & 0 & 18 & 15 & 5 & 8 & 0 & 2 & 7 & 0 & 0 & 13 & 0 & 1 & 0 & 0 & 6 & 0 & 0 & 1 & 1 & 13 & 0 & 1 & 0 & 0 & 0 & 0 & 0 & 2 & 7 & 0 \\
\hline 23 & \begin{tabular}{|l|} 
Music and \\
Theater Arts \\
\end{tabular} & 62 & 20 & $u$ & 19 & 5 & 0 & 0 & 0 & 0 & 19 & 17 & 5 & 10 & 11 & 1 & 3 & 0 & 0 & 15 & 1 & 0 & 0 & 0 & 9 & 0 & 2 & 0 & 0 & 3 & 0 & 0 & 0 & 2 & 4 & 1 & 0 & 3 & 15 & 0 \\
\hline 24 & $\begin{array}{l}\text { Nuclear Science } \\
\text { and Engineering }\end{array}$ & 78 & 22 & u & 22 & 18 & 0 & 0 & 0 & 0 & 20 & 10 & 14 & 5 & 0 & 3 & 20 & 0 & 1 & 19 & 0 & 0 & 0 & 0 & 5 & 0 & 0 & 0 & 0 & 2 & 0 & 0 & 0 & 0 & 13 & 8 & 0 & 1 & 1 & 0 \\
\hline 25 & Political Science & 117 & $24 \mid$ & U & 24 & 20 & 0 & 0 & 0 & 0 & 22 & 22 & 12 & 5 & 0 & 1 & 2 & 0 & 0 & 22 & 0 & 0 & 0 & 0 & 5 & 0 & 0 & 1 & 0 & 0 & 1 & 0 & 0 & 1 & 5 & 0 & 0 & 0 & 17 & 0 \\
\hline 26 & $\begin{array}{l}\text { Science, } \\
\text { Technology, and } \\
\text { Society }\end{array}$ & 173 & 26 & u & 25 & 22 & 0 & 0 & 0 & 0 & 24 & 21 & 20 & 3 & 2 & 2 & 6 & 0 & 0 & 20 & 0 & 0 & 0 & 1 & 2 & 0 & 1 & 8 & 0 & 10 & 0 & 0 & 0 & 1 & 10 & 0 & 1 & 1 & 7 & 0 \\
\hline 27 & $\begin{array}{l}\text { Urban Studies } \\
\text { and Planning }\end{array}$ & 168 & 26 & $\mathrm{u}$ & 26 & 24 & 0 & 0 & 0 & 0 & 25 & 23 & 10 & 5 & 0 & 2 & 3 & 2 & 1 & 22 & 0 & 1 & 0 & 0 & 4 & 0 & 4 & 4 & 0 & 10 & 1 & 0 & 1 & 3 & 3 & 0 & 0 & 0 & 17 & 1 \\
\hline 28 & $\begin{array}{l}\text { Women's and } \\
\text { Gender Studies }\end{array}$ & 51 & 19 & u & 19 & 14 & 0 & 0 & 0 & 0 & 18 & 19 & 2 & 11 & 0 & 2 & 2 & 0 & 0 & \begin{tabular}{|l|}
18 \\
\end{tabular} & 0 & 0 & 0 & 0 & 4 & 0 & 8 & 0 & 2 & 3 & 0 & 0 & 0 & 1 & 0 & 0 & 0 & 0 & 16 & 0 \\
\hline 29 & \begin{tabular}{|l|} 
Writing and \\
Humanistic \\
Studies \\
\end{tabular} & 7 & 6 & u & 6 & 3 & 0 & 0 & 0 & 0 & 6 & 6 & 0 & 2 & 0 & 1 & 0 & 0 & 0 & 6 & 0 & 0 & 0 & 0 & 0 & 0 & 1 & 0 & 3 & 0 & 0 & 0 & 0 & 0 & 0 & 0 & 0 & 0 & 6 & 0 \\
\hline & & 2704 & |629 & & 577 & 424 & 22 & 4 & 4 & 3 & 495 & 454 & 271 & 192 & 17 & 60 & 237 & 20 & 14 & $|467|$ & 31 & & 10 & 1 & 76 & & 64 & 55 & 20 & 139 & & & 4 & 15 & 199 & & & 36 & 256 & \\
\hline
\end{tabular}




\begin{tabular}{|c|c|c|c|c|c|c|c|c|c|c|c|c|c|c|c|c|c|c|}
\hline \multirow[b]{2}{*}{ No. } & \multirow[b]{2}{*}{ Program } & \multirow[b]{2}{*}{$\mathrm{N}$} & \multirow[b]{2}{*}{$\mathrm{n}$} & \multirow[b]{2}{*}{ Level } & \multicolumn{14}{|c|}{ Historical-Cultural Psychology } \\
\hline & & & & & 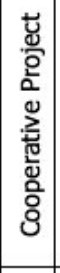 & 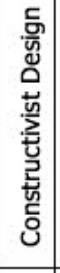 & 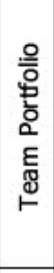 & 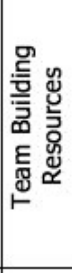 & 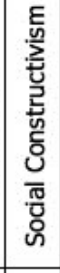 & 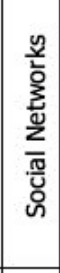 & 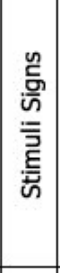 & 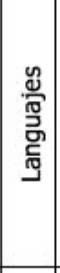 & 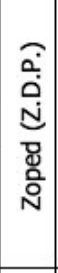 & 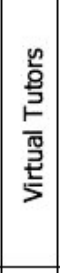 & 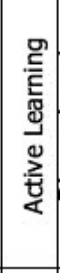 & 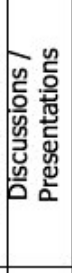 & 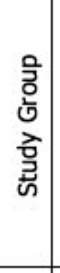 & 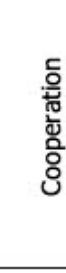 \\
\hline 1 & $\begin{array}{l}\text { Aeronautics and } \\
\text { Astronautics }\end{array}$ & 79 & 22 & $U$ & 7 & 7 & 0 & 0 & 2 & 1 & 3 & 5 & 0 & 3 & 2 & 2 & 0 & 4 \\
\hline 2 & Architecture & 104 & 24 & $\mathrm{U}$ & 6 & 11 & 0 & 0 & 6 & 5 & 4 & 5 & 1 & 5 & 5 & 5 & 0 & 2 \\
\hline 3 & $\begin{array}{l}\text { Biological } \\
\text { Engineering }\end{array}$ & 40 & 18 & $U$ & 4 & 3 & 0 & 1 & 0 & 0 & 0 & 1 & 0 & 3 & 4 & 4 & 0 & 0 \\
\hline 4 & Biology & 111 & 24 & $\mathrm{U}$ & 4 & 4 & 2 & 4 & 2 & 0 & 0 & 0 & 0 & 6 & 6 & 7 & 0 & 0 \\
\hline 5 & $\begin{array}{l}\text { Brain and Cognitive } \\
\text { Sciences }\end{array}$ & 87 & 23 & U & 6 & 3 & 0 & 0 & 4 & 4 & 1 & 4 & 0 & 0 & 0 & 15 & 0 & 11 \\
\hline 6 & $\begin{array}{l}\text { Chemical } \\
\text { Engineering }\end{array}$ & 45 & 18 & U & 0 & 0 & 0 & 0 & 0 & 1 & 0 & 0 & 0 & 0 & 1 & 1 & 0 & 2 \\
\hline 7 & Chemistry & 47 & 18 & U & 3 & 7 & & & 1 & 1 & 0 & 0 & 0 & 6 & 5 & 3 & 0 & 1 \\
\hline 8 & $\begin{array}{l}\text { Civil and } \\
\text { Environmental } \\
\text { Engineering }\end{array}$ & 98 & 23 & U & 6 & 6 & 1 & & 1 & 4 & 0 & 1 & 0 & 4 & 6 & 7 & & 1 \\
\hline 9 & $\begin{array}{l}\text { Comparative Media } \\
\text { Studies/Writing }\end{array}$ & 112 & 24 & U & 1 & 1 & 0 & 0 & 0 & 0 & 0 & 0 & 0 & 1 & 0 & 1 & 0 & 0 \\
\hline 10 & $\begin{array}{l}\text { Earth, Atmospheric, } \\
\text { and Planetary } \\
\text { Sciences }\end{array}$ & 100 & 23 & $U$ & 3 & 2 & 0 & 1 & 1 & 0 & 0 & 0 & 0 & 1 & 2 & 2 & 0 & 0 \\
\hline 11 & Economics & 82 & 22 & U & 0 & 1 & 2 & 0 & 0 & 0 & 2 & 0 & 1 & 0 & 3 & 3 & 3 & 3 \\
\hline 12 & $\begin{array}{l}\text { Electrical } \\
\text { Engineering and } \\
\text { Computer Science }\end{array}$ & 246 & 27 & U & 3 & 3 & 0 & 0 & 0 & 0 & 0 & 0 & 0 & 6 & 6 & 6 & 0 & 0 \\
\hline 13 & $\begin{array}{l}\text { Engineering } \\
\text { Systems Division }\end{array}$ & 87 & 23 & $U$ & 3 & 2 & 0 & 0 & 1 & 2 & 0 & 1 & 0 & 4 & 2 & 4 & 0 & 2 \\
\hline 14 & $\begin{array}{l}\text { Experimental Study } \\
\text { Group }\end{array}$ & 30 & 15 & U & 1 & 0 & 0 & 0 & 0 & 0 & 0 & 0 & 0 & 1 & 0 & 1 & 0 & 0 \\
\hline 15 & $\begin{array}{l}\text { Global Studies and } \\
\text { Languages }\end{array}$ & 101 & 24 & $U$ & 1 & 0 & 0 & 0 & 0 & 1 & 0 & 0 & 0 & 6 & 4 & 8 & 0 & 0 \\
\hline 16 & $\begin{array}{l}\text { Health Sciences and } \\
\text { Technology }\end{array}$ & 72 & 22 & U & 1 & 0 & 0 & 0 & 0 & 3 & 0 & 0 & 0 & 6 & 3 & 9 & 0 & 0 \\
\hline 17 & $\begin{array}{l}\text { Linguistics and } \\
\text { Philosophy }\end{array}$ & 86 & 23 & $U$ & 0 & 0 & 0 & 0 & 0 & 2 & 0 & 0 & 0 & 2 & 0 & 4 & 0 & 1 \\
\hline 18 & Literature & 118 & 24 & U & 1 & 1 & 0 & 0 & 2 & 3 & 0 & 0 & 0 & 6 & 3 & 7 & 0 & 0 \\
\hline 19 & $\begin{array}{l}\text { Materials Science } \\
\text { and Engineering }\end{array}$ & 57 & 20 & $U$ & 3 & 4 & 2 & 1 & 0 & 0 & 0 & 0 & 0 & 3 & 2 & 4 & 0 & 0 \\
\hline 20 & Mathematics & 165 & 26 & U & 0 & 0 & 0 & 0 & 0 & 0 & 0 & 0 & 0 & 2 & 1 & 2 & 9 & 0 \\
\hline 21 & $\begin{array}{l}\text { Mechanical } \\
\text { Engineering }\end{array}$ & 140 & 25 & $U$ & 3 & 3 & 0 & 0 & 0 & 0 & 0 & 0 & 0 & 0 & 1 & 1 & 0 & 0 \\
\hline 22 & $\begin{array}{l}\text { Media Arts and } \\
\text { Sciences }\end{array}$ & 41 & 18 & U & 3 & 3 & 0 & 1 & 0 & 1 & 0 & 1 & 0 & 2 & 2 & 3 & 0 & 0 \\
\hline 23 & $\begin{array}{l}\text { Music and Theater } \\
\text { Arts }\end{array}$ & 62 & 20 & $U$ & 0 & 0 & 0 & 0 & 0 & 0 & 0 & 0 & 0 & 1 & 1 & 1 & 0 & 0 \\
\hline 24 & $\begin{array}{l}\text { Nuclear Science and } \\
\text { Engineering }\end{array}$ & 78 & 22 & $U$ & 0 & 0 & 0 & 0 & 0 & 0 & 0 & 0 & 0 & 0 & 0 & 0 & 0 & 0 \\
\hline 25 & Political Science & 117 & 24 & U & 0 & 0 & 0 & 0 & 0 & 0 & 0 & 0 & 0 & 0 & 1 & 6 & 1 & 0 \\
\hline 26 & $\begin{array}{l}\text { Science, } \\
\text { Technology, and } \\
\text { Society }\end{array}$ & 173 & 26 & U & 3 & 3 & 0 & 1 & 1 & 3 & 0 & 0 & 0 & 4 & 5 & 6 & 1 & 0 \\
\hline 27 & $\begin{array}{l}\text { Urban Studies and } \\
\text { Planning }\end{array}$ & 168 & 26 & U & 4 & 3 & 0 & 2 & 1 & 2 & 0 & 1 & 0 & 3 & 5 & 6 & 0 & 0 \\
\hline 28 & $\begin{array}{l}\text { Women's and } \\
\text { Gender Studies }\end{array}$ & 51 & 19 & U & 1 & 0 & 0 & 0 & 0 & 2 & 0 & 1 & 0 & 1 & 2 & 4 & 0 & 0 \\
\hline \multirow[t]{2}{*}{29} & $\begin{array}{l}\text { Writing and } \\
\text { Humanistic Studies }\end{array}$ & 7 & 6 & U & 1 & 1 & 0 & 0 & 1 & 1 & 0 & 0 & 0 & 1 & 1 & 1 & 0 & 0 \\
\hline & & 2704 & 629 & & 68 & 68 & 7 & 11 & 23 & 36 & 10 & 20 & 2 & 77 & 73 & 123 & 14 & 27 \\
\hline
\end{tabular}

